\title{
PLATO'S HERITAGE TO WESTERN PHILOSOPHY, EUROPEAN INTELLECTUAL TRADITION AND SOME SPECIAL SCIENCES
}

\section{Danie Strauss}

School of Philosophy, North-West University, Potchefstroom Campus

dfms@cknet.co.za

\section{ABSTRACT}

Although the statement of Whitehead, asserting that European philosophy may be seen as footnotes to Plato, is exaggerated, it does provide us with a challenge to explain the element of truth in it. This article investigates a number of philosophical issues surfacing already in pre-Platonic thought in order to show how Plato mediated their impact upon subsequent philosophical developments and philosophical trends within some special sciences. The quest for a principle of origin explored alternative modes of explanation, such as number (the Pythagorean claim that everything is number), the metaphysics of space (Parmenides), the struggle with constancy and change (Heraclitus and Plato) as well as contemplating the limits of conceptual knowledge in Plato's dialogue, Parmenides. Owing to the philosophical roots of the special sciences, a more detailed account is given of the influence of Platonism upon the disciplines of mathematics, physics and theology.

Keywords: Plato; special sciences; principle of origin; metaphysics of space; Pythagoras; Parmenides; Heraclitus; philosophy; mathematics; physics; theology

\section{INTRODUCTION}

A frequently quoted and well-known statement made by Whitehead asserts that the European philosophical tradition could best be characterised as a series of footnotes to Plato (Whitehead 1929:65). This article aims at examining selected examples of

\section{UNISA}


the legacy of Plato's philosophy within the European intellectual tradition. It will take into account the influence exercised by early (pre-Platonic) Greek philosophy on the one hand, and it will focus on its significance for the subsequent development of philosophy and some special sciences on the other.

Of course the statement of Whitehead is one-sided, because non-Platonic lines of development are also important for an understanding of the history of philosophy and the various academic disciplines. In particular, one may look at Protagoras who defends his homo mensura rule: "Of all things the measure is the human being, of [things] that are, how they are, of those that are not, how they are not" (DielsKranz II, 263; Protagoras, B. Fragment 1). This nominalistic orientation opposes the dominant realistic metaphysics of the medieval era and eventually, in modern philosophy, became an equally powerful philosophical legacy, commencing with the conviction of Descartes that there is no universality outside the human mind, for Descartes considers "number and all universals as mere modes of thought" (Principles of philosophy, Part I, LVII - see Descartes 1965:187). Darwin adheres to this nominalistic position for he holds that "no line of demarcation can be drawn between species" (Darwin 1859:443) and then summarises this orientation by stating that we "shall have to treat species in the same manner as those naturalists treat genera, who admit that genera are merely artificial combinations made for convenience" (Darwin 1859:456). Simpson continues this legacy with his assertion: "[O]rganisms are not types and do not have types" (Simpson 1969:8-9). However, investigating this alternative influence of Greek philosophy exceeds the confines of this article.

A special science cannot even define itself, for such an attempt inevitably transcends the scope of the academic discipline concerned. Saying what mathematics, biology, sociology or theology is all about, differs from doing mathematics, biology, sociology or theology. Without a philosophical (theoretical) frame of reference (paradigm), which is philosophical in nature, no special science can operate. Therefore the special sciences have only two options: (a) account for the philosophical paradigm within which they work; or (b) proceed without giving such an account. In case (a) a special scientist has a (conscious and articulated) philosophical perspective and in case (b) a special scientist is (implicitly and uncritically) in the grip of such a philosophical framework (view of reality).

The objection that a special scientist is needed to say what her own discipline entails does not eliminate the just-given argument, for when a special scientist undertakes this task it remains philosophical in nature. The question is not: Who gives the definition? but: What is the nature of the definition (special scientific or philosophical)?

What is at stake is therefore to see to what extent the philosophical presuppositions of a special science reflect the influence of the legacy of Plato's philosophy. At the same time we will be able to appreciate the limits of Whitehead's claim, because 
asserting that the European philosophical tradition could best be characterised as a series of footnotes to Plato (Whitehead 1929:65), certainly overstates the case.

The perennial issues selected for discussion are the issue of unity and diversity; infinity in the sense of an endless progression (one, another one, and so on indefinitely) and infinity turned "inwards" (the infinite divisibility of what is continuous); constancy and dynamics, and the difference between conceptual knowledge and concept-transcending knowledge. Plato's contribution will be contextualised within Greek philosophy. However, we commence by looking at the idea of an origin (Archē) within early Greek philosophy, keeping in mind that in a certain sense the philosophy of Plato transformed and reconfigured these early Greek views.

\section{Early Greek philosophy}

Similar to our everyday experience of a rich diversity of entities and properties, Greek philosophy commenced with a search after the principle of origin of this diversity. Copleston observes that amidst this diversity philosophers were looking for the "underlying unity" of what they chose as the "first principle" (Copleston 1985:23).

Any student of Greek philosophy is familiar with options chosen by Thales, Anaximines and Heraclitus, namely water, air and fire (see Diels-Kranz, Thales, B Fr. 3; Diels-Kranz, B Fr. 3; and Diels-Kranz, B Fr.30). Of interest is that in spite of the assumed fluid nature of these principles of origin, Heraclitus (Diels-Kranz B Fragment 30) holds that the world-ordering is not created by one of the Gods or by humans, because it was always there as an eternal living fire. Anaximander proposed the unlimited-infinite (apeiron) as principle of origin and characterises it in a way similar to the fire of Heraclitus. In his second B Fragment Anaximander states that "the apeiron is without ageing" and in the third that "the apeiron is immutable and incorruptible."

Parmenides took this mode of thinking further by declaring that non-being is unthinkable and unsayable (Diels-Kranz, B Fr.8:8-9). His positive characterisation of being (of what is) reads that it is unborn and incorruptible, for it was not and will never be, for in the now it is present as a whole, one, continuous (Diels-Kranz, B Fr.8:3-6). These hallmarks of "being" are largely characterised by the employment of spatial features, ${ }^{1}$ because spatial extension is continuous and given as a coherent whole. ${ }^{2}$ It is therefore a sign of the space metaphysics of Parmenides that he denies any divisibility of (continuous) being (see Diels-Kranz, B Fr. 8:25). ${ }^{3}$ Both Fränkel

1 This philosophy of being eventually found its way via Plato into the medieval "chain of being" with God as the highest being (ipsum esse) (Thomas Aquinas, Summa Theologica, I,13,11).

2 The whole-parts relation was discovered by Zeno (see Diels-Kranz B Fr.3).

3 In Book VI of his Physics Aristotle is correct when he states: "everything continuous is divisible into divisibles that are infinitely divisible" (see Aristotle, 2001: 317; Phys. 231b:15-16. 
and Guthrie interpret Zeno's B Fragment 3 in terms of the (spatial) whole-parts and parts-whole relation (see Fränkel 1968:430 and Guthrie 1980:88 ff., 512; see also Guthrie 1980:90-91).

According to Riedweg the school of Pythagoras substituted what Thales called water, Anaximines air and Heraclitus fire with "number" (Riedweg 2005:80) (see the discussion of arithmetised mathematics in Fowler 1999:8 ff.).

Comparing Pythagoras and Parmenides makes it plain that they explored alternative modes of explanation: number and space. The Pythagoreans observed in the cosmos relationships between numbers which, according to Lorenzen, relate to the rise of atomism (Lorenzen 1960:47).

A crisis emerged with the discovery of incommensuralibility, which demonstrated the limitations of attempting to reduce everything to the ratios of integers. ${ }^{4}$ It is possible to represent every numerical relationship in a geometrical fashion, but it is not possible to represent every relationship between spatial linestretches arithmetically (see Lorenzen 1960:51 and Laugwitz 1986:9). This insight resulted in the geometrisation of Greek mathematics ${ }^{5}$ - the opposite of its initial arithmetisation. However, a distorted perspective on space was continued in the philosophy of Parmenides because he interpreted extension as an indivisible whole (see Diels-Kranz, B Fr. 8:22-25).

These restrictions were transcended when Empedocles introduced four immutable ontic forms, namely fire, earth, air and water - which, according to Aristotle, should be treated as two: fire as opposed to earth, air and water (cf. Metaph., 985 b 1-3; Aristotle, 2001:697). This separation conforms to the two soulforces of Empedocles, namely love (philia) and animosity (neikos). The fluid divine nature of the philia, in opposition to the neikos as a non-divine soul force (cf. D-K, Diels-Kranz, B Fr. 59), shows that the matter motive is partially de-divinised; only in connection with the neikos. However, according to Anaxagoras the nous is not determined by any limits; it is not intermingled with germs of matter, and is selfsufficient. To him we also owe a further elaboration of the insight that something continuously extended is indefinitely divisible (Diels-Kranz, B Fr. 3). Later on Aristotle, on the basis of the distinction between the potential and the actual infinite, specified the other property of continuity (every point of division ought to be taken twice): "In the act of dividing a continuous distance into two halves, one point is treated as two, since we make it the starting-point and a finishing-point: ... and

$4 \quad$ What was later designated as form and matter, was initially also described as the limited and unlimited (peras and apeiron). It appears, for example, that the formatively-delimited oblique side of a rectangular triangle with two rectangular sides with a length of 1 , in itself (from an arithmetical perspective) contains an infinite (unlimited) sequence. In other words, in this case the apeiron abrogated the delimiting function of the peras! The delimiting function of number was therefore actually questioned by the discovery of irrational numbers (incommensurability - cf. Von Fritz 1945:242-264).

5 Note that no attempt was launched to resolve this impasse by using the idea of infinite totalities. 
although that which is continuous contains an infinite number of halves, they are not actual but potential halves" (Aristotle 2001:383-384; Physica, 263 a 23ff.). Böhme strikingly shows how Cantor's definition of the continuum contains two stipulations which both meet the Aristotelian definition of a continuum, namely coherence and a characteristic which ensures the existence of dividing points for infinite divisions (Böhme 1966:309).

\section{The static world of ontic forms and the dynamic world of becoming}

Plato's theory of ideas crucially depends on these developments within early Greek philosophy. It first of all responds to the lasting problem of constancy and change, for if everything changes no knowledge would be possible. According to Plato, knowledge presupposes enduring ontic forms, each with its own essence (auto to eidos). This entails another lasting problem, namely how to relate diversity to a unity (the problem of the one and the many). Add to this that the motivating basic motive of matter and form directed Plato's thought towards an attempt to bridge the gulf between the intelligible realm of eternal ontic forms and the phenomenal world of becoming which is subject to the matter principle (see Politeia $509 \mathrm{~d}-511 \mathrm{e}$ ). The dialogue Phaedo distinguishes between what is invisible and constant and that which is visible and changeable (thought and the senses). ${ }^{6}$

The static unity of the eide had to provide a foundation for the (composite) world of becoming by allowing the phenomena to partake or share in the eide (methexis, parousia, koinonia) (Phaedo $100 \mathrm{D}$ ). Implicit in this issue is the problem of the one and the many. How can what is simple and one cause the many? Surely, if Plato continues the initial Eleatic understanding of the eidos as something simple and indivisible, this problem cannot be solved. The authentic Platonic theory of ideas probably ensued from what Parmenides and the Pythagoreans thought, combined with the conceptual method of Socrates (regarding the dynamic tendency in the thought of Socrates see Plato Euthyphro 5 D).

In the dialogue Cratylus it is argued that if something is caught up in continuous change, then knowledge of it would be impossible, for the moment it is approached in knowledge, it has become something different already (Cratylus $439 \mathrm{e}-440$ a). This coheres directly with the problem of change that will exclude knowledge: if the

6 The soul apart from the body is directed at the world of the pure and eternal, immortal and unchanging, constant and equally natured things (Phaedo 79d) and it exhibits the greatest similarity to the divine, immortal, conceivable, simple indissoluble, constant and "self-identical". The body in turn displays the greatest similarity to the human, mortal, multifarious, nonconceivable, dissoluble and never-constant (Phaedo 80b:1-6). This dualism is manifest in the thought of Aristotle where the "highest matter principle" as dunamei on merely remains the dialectial opposite of pure, actual form (Happ 1971:562). 
auto to eidos of knowing changed into another eidos, no knowledge (to subject and object) will be possible (Cratylus $440 \mathrm{a}-\mathrm{b}$ ).

Apparently Aristotle has this in mind when he points out that Plato was acquainted with the doctrines of Heraclitus according to which "all sensible things are ever in a state of flux and there is no knowledge about them" (Metaph. 987 a 30; Aristotle 2001:700). This highlights a basic problem that still needs to be addressed by any critical theory of science in service both of philosophy and the special sciences.

\section{The idea of the good and the multiplicity of eide}

In his Republic Plato has to relate the unity of the idea of the good with the multiplicity of eidē. He argues that the objects of knowledge derive from the good not only their power of being known, but also their very being and reality; and goodness is not the same thing as being, but even beyond being, surpassing it in dignity and power (see Politeia $509 \mathrm{~d}-511$ e).

The focus of Plato's argumentation on the idea of the good, which exists in elevated power and dignity and which provides knowability to the objects of knowledge, is quite significant. Krämer even remarks: "The closing section of Book 6 of Politeia, to be more precise, the section $508 \mathrm{D}-509 \mathrm{~B}$, concerns the acknowledged most important part of his entire dialogical work" (Krämer 1959:473).

From the comparison of the good with the sun it appeared that the eide owe their existence, being and knowability to the idea of the good. Viewed in coherence with the nature of the divine workman, it is nonetheless clear that the eide originate from the idea of the good having its seat in the divine Demiurge. Jäger (1967) treats the relation of the nous to the agathon where he elucidates the active operation of the nous in its focus on ordering (Jäger 1967:106 ff.). The continued influence of Anaxagoras and Socrates (nous and dynamics) is clear: as workman, the divine nous is, through the primordial design of the idea tou agathou, the origin of the eide, and also the form-giver of the world of the senses.

\section{Plato acknowledges the limits of conceptual knowledge}

Although the narrator provides a closer circumscription of justice in terms of a synoptic intuition of its essence, it appears that a more precise determination of the idea of the good as concentric primordial form is not possible at all. Already in Politeia $506 \mathrm{~d}$ 6-10, we meet an evasive answer by Socrates, namely that a circumscription of the good transcends his powers and that consequently he has to be satisfied with comparing the good with the sun. According to Plato the synoptic intuition of essence (phrased in modern terms: the human ability to conceive) certainly falls short when an account of the idea tou agathou as original form of the divine workman is required. For this reason he also cannot provide a "conceptual definition" of it. W. 
Jaeger remarks: "Plato does not try, even in the succeeding sections of the book, to define accurately the nature of Good itself" (Jaeger 1945:282; Wichman 1966:29), which shows that Plato wrestles with the limits of concept formation and with the nature of concept-transcending knowledge.

As an effect of the initial metaphysical duplication of the world of the senses, the eide themselves ultimately function as a genuine diversity (multiplicity), apart from allowing sensory phenomena to partake in these universal, static ontic forms

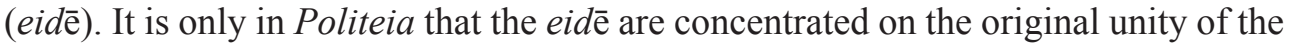
idea of the good of the divine workman (demiourgos).

Yet, in all of this the grand conception of Plato's theory of ideas in the Republic continued to struggle with the principles of form and matter. Essentially these two principles mutually oppose each other, showing that the above-mentioned doctrine of methexis, koinonia and parousia has not yet made any real progress. The lasting problem concerns the intelligible realm of the eternal ontic forms and the sharply distinguished visible realm of phenomena subject to the matter principle of becoming.

\subsection{The dialectical logic of Plato's dialogue Permenides}

The connection with Politeia explains why Plato withdraws the absolute One (which is the Good) from all conceptual determinations in Parmenides. This contradicts the basic intention of Parmenides who actually identified true thought and being. However, what Plato aims at demonstrating in this dialogue (Parmenides) is that any attempt to grasp the absolute One conceptually reveals the limitations of human thought. Concerning the One as absolute form-giving origin nothing could be expressed in positive conceptual terms.

In the Politeia the idea of the good is the primordial image of the divine Demiurge in which the eidē are concentrated. But it merely serves as form-giver of the sensory world of becoming. The same dialectic appears in the Parmenides in the form of the opposition between the One and the Unlimited Other.

The first antinomy proceeds from the assumption that the One is absolutely one. But then it is impossible to say that it is a whole, for a whole is that which contains all its parts, implying that the One then is many (137 c 4d 3). Likewise the One is without limits (137 d 7-8) and formless (neither round, nor straight: $137 \mathrm{~d}$ 8-e 1). In the further elaboration of this antinomy, the narrator shows that the One is nowhere (neither in itself, nor in something else), that it does not move nor prevail in a state of rest, that it is not identical or different from itself, not similar or dissimilar to itself or anything else, and so on (138 a-142 a). Thought through consistently in this sense, nothing positive can be said of the absolute One.

In the fourth antinomy the same conclusions are drawn with respect to the Other (the Unlimited Many). If the One is absolutely one then the Other does not exhibit unity, two-ness or multiplicity, then it is not a whole and parts, not equally 
or unequally natured in respect of itself or something else, not in motion or at rest, and so on (159 e-160 b). Where the first antinomy carries the Eleatic hypothesis to a strictly negative conclusion, namely that the absolute One does not participate in any determinations of being (that applies in the same sense in the fourth antinomy to the Other), the second and third antinomies pay attention to the positive implications of the supposition that the One indeed participates in metaphysical being. The conclusion of the first four antinomies reads as follows: Therefore "if the One is, it is all things and is nothing, in relation both to itself and to the Many" (160 b 1-3). We also mention the complex formulation of the summarising conclusion of all eight antinomies. "Whether the One is or is not, both the One and the Many are and also are not, appear and do not appear to be, all manner of things, in relation both to themselves and to one another" (166 c 1-5).

What the dialogue Parmenides therefore shows is that as soon as the dialectical understanding of the origin is thought through in a positive fashion, it gets entangled in the antinomic affirmation and denial of all properties, both in respect of the One and the Many - or else thinking simply terminates in the total negation of all determinations of being (i.e., conceptual determinations).

The negative implications connected in Parmenides to the acquisition of knowledge of the form-giving origin are pertinently highlighted by Krämer: "In its straight-away transcendence and absoluteness the Ground withdraws itself from the grasp of discursive thinking, that always presupposes Multiplicity, and is therefore in a strict sense indefinable, impredicable and beyond the grip of language" (Krämer 1959:543-544). Krämer also explicitly speaks of the One as limit concept. "The noetic experience of the Ground manifests itself only in passing through the progressing discursive abstraction from the world and the negation of multiplicity, that is to say, through the limit concept (Grenzbegriff) of the One, and the vision of absoluteness liberates the discipline of the being of being only over the negative dialectical road (via negativa) of the One" (Krämer 1959:545, cf. page 466). Also in his work on the origin of the nous metaphysics, Krämer writes: "In the platonicacademic stoicheion-system the Hen [One] as ultimate element and highest genus can no longer be conceptually determined, for it allows only a negative circumscription" (Krämer 1964:118).

From the preceding analysis it is clear that Plato responded to and was influenced by the following basic problems surfacing in the pre-Platonic philosophical developments.

1. The initial problem regarding the one and the many became a perennial problem of philosophy as such.

2. The Pythagorean choice for number as mode of explanation experienced a crisis through the discovery of incommesurability (irrational numbers).

3. This made room for the "geometrisation" of Greek mathematics. 
4. The effect was that being was understood in spatial terms (as a coherent whole).

5. Parmenides attempted to divorce being from multiplicity and movement.

6. Yet, from Empedocles to Anaxagoras being was "split up", paving the way for the subsequent acknowledgment of the infinite divisibility of what is continuous.

7. In his dialogues Politeia and Parmenides, Plato explored the positive and negative sides of the limitations of conceptual knowledge.

8. Plato combined and transformed these problems within his own intellectual development.

a. Plato's theory of the eide - eternal supra-sensory static ontic forms explores an answer to the problem of the one and the many.

b. It also responds to the problem of what is universal (the ontic forms) and what is individual (copies of the eide within the changing phenomena of the sensory world of becoming) - elaborated in his peculiar view of methexis, koinonia and parousia.

c. These developments incorporated features that eventually contributed to the fruitful introduction of actual infinity in mathematics (to which we shall return below).

d. The underlying dialectic of the form-matter basic motive of Greek philosophy informed Plato's acknowledgment of the idea of the good (the "One" in his dialogue Parmenides) exceeding conceptual understanding.

We may now consider the lasting effect of some of these issues within the intellectual legacy of the West by looking at mathematics, physics and theology.

\section{Modern mathematics}

\subsection{Plato and the first foundational crisis of mathematics}

In the second edition of their standard work on Foundations to set theory Fraenkel et al. identify three foundational crises in the history of mathematics (Fraenkel, BarHillel, Levy and Van Dalen 1973:12-14). They point out that the first crisis emerged when it was discovered that not "all geometrical entities of the same kind were commensurable with each other, so that, for instance, the diagonal of a given square could not be measured by an aliquod part of its side...in modern terms that the square root of 2 is not a rational number."

They mention the fact that this discovery made such an impression on Plato that he reported in his dialogue Theaitetos (147 d) that "Theodorus had proved the 
irrationality of the square root of 3, 5.. 17" (Fraenkel et al. 1973:13 note 1 and Reidemeister 1974). ${ }^{7}$

\subsection{The second and third foundational crises}

The second crisis surfaced in connection with the irresponsible use of infinitesimals and how the notion of a limit could be treated by arithemetising analysis and function theory. Apparently a more satisfactory account of real numbers was developed during the later part of the $19^{\text {th }}$ century when a key element of modern (mathematical) Platonism was employed, namely the idea of an infinite totality. ${ }^{8}$ Unfortunately the culmination point of this (arithmeticistic) development at once harboured its deepest fall. On the one hand, Poincaré made the proud claim in 1900 (at the second international Conference of Mathematicians) that today "there remain in analysis only integers and finite and infinite systems of integers...Mathematics...has been arithmetized...We may say today that absolute rigour has been obtained" (Fraenkel et al. 1973:13-14 - see also Poincaré 1902 and Poincaré 1910). However, the independent discovery made by Russell and Zermelo (in 1900 - cf. Husserl 1970:xxii, 399ff) showed that "naive set theory" allows for the following contradictory set: the set $C$ having as elements all those sets not having themselves as an element. For example, the set of 20 words is a set and not a word - and therefore does not contain itself as an element. But the set of all imaginable sets is imaginable and therefore does contain itself as an element. Contemplate now two cases: (i) $C$ is an element of $C$ and (ii) $C$ is not an element of $C$. If (i) holds, then $C$ must conform to the condition for being a member of $C$, namely that it is not an element of itself. And vice versa (ii): if $C$ is not an element of $C$ then it does conform to the condition for being an element of $C$ - from which the contradiction follows: $C$ is an element of $C$ if and only if it is not an element of $C$.

This situation caused Fraenkel et al. to remark:

Ironically enough, at the very same time that Poincaré made his proud claim, it has already turned out that the theory of the infinite systems of integers - nothing else but part of set theory - was very far from having obtained absolute security of foundations. More than the mere appearance of antinomies in the basis of set theory, and thereby of analysis, it is the fact that the various attempts to overcome these antinomies...revealed a far-going and surprising divergence of opinions and conceptions on the most fundamental mathematical notions, such as set and number themselves, which induces us to speak of the third foundational crisis that mathematics is still undergoing. (Fraenkel et al. 1973:14)

7 Plato writes: "Theodorus here was demonstrating to us with the aid of diagrams a point about powers. He was showing us that the power of three square feet and the power of five square feet are not commensurable in length with the power of one square foot; and he went on in this way, taking each case in turn till he came to the power of seventeen square feet" (Theaitetos $147 \mathrm{~d}$ ).

8 Gray mentions that one of the novel ideas in 19th and 20th century mathematics is found in the way in which "Dedekind and Cantor (and others)" defined the real numbers "in terms of infinite sets" (Gray 2008:16). 
This third foundational crisis generated diverse and even radically opposing reactions. In 1904 Zermelo published an article in which he developed the first axiomatisation of set theory, with in-built restrictions aimed at avoiding the possibility of construing the contradictory sets discovered by Russell and himself - later on amended by Fraenkel and currently known as ZF set theory (ZermeloFraenkel set theory). Russsell reacted with his logicism (ramified type theory) and found in Gödel another supporter of logicism ${ }^{9}$ (although the latter did have an eye for the limitations of logical definitions when it comes to truly primitive terms). ${ }^{10}$ The intuitionism of Brouwer, Heyting and Weyl, ${ }^{11}$ in turn, launched a radical critique on classical mathematics as well as axiomatic set theory. The logicism of Russell views mathematics and logic as identical (Russell 1956:v), while Hyeting aims at the opposite in his claim: "every logical theorem... is but a mathematical theorem of extreme generality; that is to say, logic is a part of mathematics, and can by no means serve as a foundation for it" (Heyting 1971:6 - see also Strauss 2004:39 and 45 ff.).

The contrasting appreciation of Cantor's transfinite arithmetic is astonishing. Hilbert values Cantor's transfinite arithmetic "as the most wonderful flourishing of a mathematical spirit and as such one of the highest achievements of pure human intellectual activity" (Hilbert 1925:167), while A. Heyting considers transfinite arithmetic as no more than a phantasm (Heyting 1949:4).

The famous proof of Gödel in 1931, which shows that every axiomatic system requires and presupposes an insight transcending the formalism of the system, gave the student of Hilbert, Hermann Weyl, sufficient grounds for writing: "It must have been hard on Hilbert, the axiomatist, to acknowledge that the insight of consistency is rather to be attained by intuitive reasoning which is based on evidence and not on axioms" (Weyl 1970:269).

\subsection{Both intuitionism and Platonism are influenced by Greek philosophy}

The most crucial point of difference between axiomatic formalism and intuitionism is found in their respective appreciation of the meaning of infinity. Traditionally two kinds of infinity are distinguished, the potential infinite and the actual infinite. Intuitively this distinction concerns succession without an end (endlessness), the successive infinite and an infinite multiplicity given at once (the at once infinite).

9 Myhill remarks that the position assumed by Gödel "presupposes Platonism" (Myhill 1952:186).

10 Yourgrau mentions that Gödel "insisted that to know the primitive concepts, one must not only understand their relationships to the other primitives but must grasp them on their own, by a kind of 'intuition'" (Yourgrau 2005:169).

11 In a paper presented in 1931 Weyl claims that it is the "great achievement" of Greek mathematics that it made the tension between what is finite and infinite fruitful for our knowledge of the world. To this he adds the observation: "Yes, precisely now we see ourselves induced everywhere in the foundations of mathematics to go directly back to the Greeks" (Weyl 1931:1). 
The initial Pythagorean line of thought in Greek philosophy pursued the successive infinite (endlessness and infinite divisiblity). However, the discovery of incommensurability generated the first crisis of mathematics (Von Fritz dedicated special study to this issue - see Von Fritz 1945 and Riedweg 2005:26, 29, 103, 107, 109-110). The ensuing "geometrisation" of mathematics prevented Greek mathematics from developing a sound theory of irrational numbers. At the hands of Weierstrass, Dedekind and Cantor (during the last part of the $19^{\text {th }}$ century) such a theoretical account was introduced on the basis of employing infinity in the sense of the at once infinite.

The development of Greek philosophy has shown that the idea of being (Parmenides) highlights crucial features of space, such as its continuity and the spatial whole-parts relation, embracing all its parts at once. We noted that Parmenides holds that being was not and will not be, because in the now it is jointly present as a whole, one, cohering (continuous). Plato explored this idea of being in his own way in his understanding of eternal, static ontic forms. Characterising this transcendent realm in spatial terms (the whole-parts relation) laid the foundation for the employment of the at once infinite and for the way in which reference is made to Platonism in mathematics.

In a well-known paper of Bernays on Platonism in mathematics he mentions that the weakest Platonistic assumption is found in the idea of the totality of integers (die Gesamtheit der ganzen Zahlen) (Bernays 1976:63). Bernays was the co-worker of the leading mathematician of the $20^{\text {th }}$ century who co-published a two-volume work (1934, 1939) on the foundations of mathematics (Die Grundlagen der Mathematik). In 1925 Hilbert presented a paper on the infinite (Über das Unendliche) which appeared in the Mathematische Annalen of the same year. In it he distinguishes the successive infinite and the at once infinite. According to him the potential infinite differs from the proper infinite ("das eigentlich Unendliche"). The latter is present when we view "the totality of the numbers $1,2,3,4$, itself as a completed unity... This kind of infinity is designated as the actual infinite" (Hilbert 1925:167).

His general assessment is that the application of Platonism in mathematics is so widespread that it is not an exaggeration to say that today it reigns in mathematics ("der Platonismus sei heute herrschend in der Mathematik" - Bernays 1976:65).

Modern mathematicians do not realise that the idea of a totality (and the wholeparts relation entailed in it) derives from our intuition of space and spatial continuity. Perhaps Paul Bernays approximates it closely when he remarks: "The idea of the continuum is a geomerical idea which analysis expresses in an arithmetical language."'12

In contrast to this view the intuitionist mathematician who left the axiomaticformalist approach of Hilbert, namely Hermann Weyl, accuses the employment of

12 "Die Idee des Kontiuums ist eine geometrische Idee, welche durch die Analysis in arithmetischer Sprache ausgedrückt wird" (Bernays 1976:74). 
the idea of infinite totalities as the basic sin of mathematics: "This is the Fall and original sin of set-theory, for which it is justly punished by the antinomies" (Weyl 1946:10).

We merely have to look at Cantor's definition of a set to see how thoroughly the Parmenidian and Platonic legacy is digested in the idea of the at once infinite. Cantor defines a set as follows: "Under a 'set' we understand every collection $M$ of determined, properly distinguished objects $m$ of our intuition or our thought (which are designated as the 'elements' of $M$ ) into a whole" ([zu einem Ganzen] Cantor 1897:481; Cantor 1962:282). There are two primitive terms in this definition: (i) the (arithmetica) notion of a multiplicity (properly distinguished objects) and (ii) the (spatial) notion of a whole (totality). When a successively infinite sequence of numbers is contemplated in terms of Cantor's definition of a set, it immediately gives rise to the idea of an infinite totality.

\subsection{Eternity as the timeless present - Greek support for the actual infinite}

Closely connected to this idea of the actual infinite is the interpretation of eternity as the timeless present. It is already found in the thought of Plotinus and it influenced the subsequent connection of infinity with the present. Understanding eternity as the timeless present is also found in the thought of Boethius (Consolatio Philosophiae), Augustine (Confessiones XI,11,13; De Trinitate XII,14), Thomas Aquinas (Summa Theologica I,10) and Schilder (1948:61).

Augustine went further than Plotinus by stating that our inability to comprehend the infinite should not be used as a measure for God, since God in his omniscience understood every infinity - also the completed infinite set of all numbers. In Book XII (Chapters 18 and 19) of his City of God (cf. Also Heimsoeth, H. (n.d.:68) Augustine acknowledges the distinctness of every number (no two numbers are the same) and allows for viewing them collectively as infinite: "Moreover, each number is so defined by its own properties, that no two numbers are equal. They are therefore both unequal and different from one another; and while they are simply finite, collectively they are infinite" (Augustine 1890:383).

A provisional point of rest is found in the view of Cusanus, according to whom the cosmos is potentially infinite and God actually infinite (Cusanus 1997:I,5; II,3). Maimon continues this tradition by distinguishing a finite and an absolute understanding. He holds: "an infinite number (because our perception is bound to the form of time), cannot be represented other than as an infinite succession in time (which consequently is not capable of being completed). In the case of an absolute understanding, by contrast, the concept of an infinite number is thought of at once, without any passage of time...For this reason that which understanding, according to its limitation, views as a mere idea, according to its absolute existence is viewed as a real object" (Maimon 1790:228). 
Every appeal to a multiplicity of numbers given at once as a whole explores one or another key feature of the spatial aspect, implicitly built upon the assumption that succession embodies what is temporal while simultaneity (at once) constitutes eternity. In fact however, one should merely distinguish between the original meaning of number (endlessness) and the coherence between number and space viewed from the perspective of the numerical aspect, in which case we meet the (spatially) deepened number-idea of infinite totalities.

Sometimes an author will also appeal to the modern notion of "spacetime". For example, Chase recently remarks that "we must think of spacetime as constituting an indivisible whole" (Chase 2014:73). This characterisation closely resembles what Parmenides said in Diels-Kranz, B Fr. 8:22! Chase adds that this reminds us of Pierre Hadot's "view from above", by means of which, the soul is "capable of observing the totality of space and time" (reminding us of what Augustine and Maimon said - see Chase 2014:74).

When it is held that a divine mind (or God) has the ability to observe the totality of a numerical succession at once, we are merely speculatively elevating the original meaning of infinite totalities to the level of the divine. Cantor confronted the critics of his mathematical employment of the actual infinite (the at once infinite) with the views of Augustine, who believed, as noted, that God can oversee the actual infinite sequence of integers as an actually-infinite quantum (Cantor 1962:401-403).

Although Lorenzen rejects the idea of the at once infinite, his description of it incorporates the legacy of combining infinity, time and eternity. According to him the at once infinite is incorporated in the modern concept of a real number, which allows for recognising its descent from geometry [given at once - reflecting the spatial order of simultaneity]:

Much rather all real numbers are imagined as really present at once....and thus every real number as an infinite decimal fraction is already represented as if the infinite multiplicity of numbers all exist at once (auf einmal). (Lorenzen 1972:163)

Our remarks about modern mathematics merely intended to highlight the fact that the two main schools of thought found in $20^{\text {th }}$ century mathematics (intuitionism and axiomatic formalism), are both dependent upon key features present in Greek philosophy that were mediated by Plato. This assessment applies in particular to the difference between the successive infinite and the at once infinite, since these two kinds of infinity are rooted in Greek philosophy.

\section{Modern physics}

We now have given a brief indication of the development of early Greek thought in terms of alternative ideas regarding the origin of the cosmos. Initially the elements chosen were thought of as flowing, dynamic principles of origin, because at this 
early stage of Greek thought the motive of form, measure and harmony played a subordinate role. Yet the dialectical tension between form and matter (the formless) explored alternative modes of reality providing a partial understanding of material things. ${ }^{13}$

\subsection{Greek philosophy and the mystery of matter}

This may be one way of understanding the mystery posed by the question what matter actually is. If alternative modes of explanation enable only partial answers from functionally distinct angles of approach, then merely making an appeal to these angles of approach will never solve the problem. It is, therefore, not surprising that Stegmüller believes that one of the most difficult questions facing science in the contemporary physics is indeed the concept of matter, which, according to him, is mysterious to an utmost degree (he addresses this issue in a paragraph on "Die rätselvolle Materie" [“The mysterious matter"] - Stegmüller 1987:89 ff.).

What Stegmüller has in mind is the old adage that there are no jumps in nature; that it is continuous ("natura non facit saltus"). It derives from the philosophy of Leibniz who postulated it as the law of continuity (lex continui) (see Leibniz 1965:152, 156). However, it should be remembered that there is an important difference between physical space and mathematical space - the former is discontinuous and not infinitely divisible (since it is bound to the quantum-structure of energy), while the latter is both continuous and therefore does allow for infinite divisibility.

Does the acknowledgement of discontinuity, continuity or infinite divisibility help us to understand what matter "really" is? Stegmüller is sceptical about this for according to him we are "not wiser than before" especially in comparison with those first thinkers who attempted more than 2000 years ago to provide a speculative foundation for matter (Stegmüller 1987:91).

\subsection{An atomistic conception and a continuity conception}

When Stegmüller continues his explanation of the problems attached to an understanding of the nature of matter, the first four aspects of reality already explored in Greek philosophy suddenly acquire a new actuality. In the first place, he distinguishes two global basic conceptions regarding the nature of matter and points out that these conceptions once again, as previously, occupy a prominent place in current discussions. He calls these two basic conceptions the atomistic conception

13 We leave aside the immanent critique of the dualism in Plato's thought regarding the schema of ontic form (Urbild) and copy (Abbild). If the visible world, governed by the matter principle of becoming, is supposed to instantiate eternal ontic forms, then within the transcendent world of ontic forms there must be a form for the formless matter. This problem gave rise to the dialectical logic of his Eleatic dialogues and eventually to his idea tou apeiron (ideal matter) - and under the influence of Pythagoreanism to the notion of "ideal numbers". 
and the continuity conception (Stegmüller 1987:91 ff.). Laugwitz also points out that insofar physics subjects itself to mathematics, it cannot escape from the polarity between continuity and discreteness ${ }^{14}$ (a problem, as we noted, that also confronted Greek mathematics - Laugwitz 1986:9). ${ }^{15}$

Suddenly the question concerning the infinite divisibility of matter once again occupies a central position. Clearly this distinction between "atomism" and "continuity" presupposes the unique meaning of number and space.

\subsection{Indestructibility versus transformability}

However, Stegmüller proceeds by referring to another problem:

i. The apparent indestructibility of matter; and

ii. The apparent or real limitless transformability of matter (Stegmüller 1987:91).

This second problem-complex concerns the relation between constancy (indestructibility) and change (transformability) which makes an appeal to the kinematic and physical aspects of reality. That the meaning of constancy is presupposed in change was seen by Plato, for in order to secure the possibility of knowledge he postulated the constancy of the essential (ontic) being of things (their static eidos). These transcendent ontic forms were supposed to lack change (Cratylus, $439 \mathrm{c}-440 \mathrm{a}$ ). Without an awareness of endurance (persistence), the very notion of change becomes problematic, for the difficult question is then: 'what' changes? For example, only when we are referring to the same person is it meaningful to state that such a person is ageing. That one can detect changes only on the basis of constancy is the lasting insight of Plato's theory of ideas. While we may distance ourselves from the speculative (metaphysical) construction of transcendent ideal forms (static essences), we still have to account for the brilliant insight that change presupposes constancy.

The legacy of Plato in this regard is threefold:

iii. Plato's insight that change presupposes constancy forms the basis of Galileo's law of inertia. This law states that a body in motion will continue its movement endlessly unless something impinges upon it, such as friction or gravity.

14 Just recall the discovery of incommensurability mentioned earlier.

15 Interestingly d'Espagnat does not acknowledge the fact that the whole-parts relation already surfaced in Zeno's third B Fragment for he characterises classical physics "to be a multitudinist worldview" favouring a conception of nature in which reality basically is constituted by "myriad simple elements - essentially localised 'atoms' or 'particles'." He believes, however, that the more general "quantum field theory is radically at variance with it" with its alternative "notion of a wholeness of some sort". He states: "But theoretical as well as experimental advances gradually made people realise that it [wholeness] constitutes an inherent part of the very quantum formalism and has quite specific experimental consequences" (d'Espagnat 2006:17). 
iv. This insight constitutes the core of Einstein's special theory of relativity, for according to this, all movement is relative to the vacuum velocity of light. ${ }^{16}$ Strictly speaking, this theory is therefore first of all one of constancy.

v. The first main law of thermodynamics, namely the law of the so-called conservation of energy, could be formulated in a more precise way (on the basis of Plato's insight), simply by designating it as the law of energy constancy. The notion of conserving suggests an (unintended) energy-input-a misunderstanding not supported by the phrase "energy constancy".

In his work on the harmony of the universe, Kepler accepts elements of the traditional realistic metaphysics, in particular the presence of creational ideas in God's mind (where these ideas are understood as Plato's eidē). Von Weizsäcker explains that since physics has to think the divine thoughts of God, it is the true religion (Gottesdienst) (Von Weizsäcker 2002:54).

\section{Theology}

\subsection{Negative theology}

The (early) medieval legacy of a negative theology (including the Cappadocians) was influenced by Plato's dialogue Parmenides (see paragraph 3 above). Even today it is still alive in the views of Radical Orthodoxy (see below). The influential substance concept, with its distinction between essence and appearance, received a strong stimulus from Plato's distinction between the transcendent ontic forms ("essences") and their copies (appearances) within the world of becoming. ${ }^{17}$

We noted that the dialogue Parmenides advanced a dialectical understanding of the origin of the cosmos, manifested in the opposition of the One and the Many. Any positive claim gets itself entangled in the antinomic affirmation and denial of all properties, both in respect of the One and the Many. Alternatively, thinking simply terminates in the total negation of all (conceptual) determinations of being. Compare now the arguments of Plato with the negative theological approach of Clement of Alexandria (150215) who was convinced that what could positively be said about God does not touch his essence, for such propositions merely elucidate what God is not. Clement holds that God in his simplicity is unknowable (see Mühlenberg 1966:74). This simplicity metaphysics (influenced by Xenophanes and Plato - simple in the sense of excluding multiplicity) postulates an absolute unity which is similar to the

16 In his special theory of relativity Einstein postulates the principle of the constant velocity of light ["Prinzip von der Konstanz der Lichtgeschwindigkeit"] (Einstein 1982:30). In his autobiographical notes he explains the presupposition that the vacuum-velocity of light is constant [“die Voraussetzung von der Konstanz der Vacuum-Lichtgeschwindigkeit"] (Einstein 1959:54).

17 In passing it should be noted that Plato directly influenced the thought of Aristotle in many ways as well (see Verdenius and Waszink 1968). See also Ter Horst (2008). 
One in the philosophy of Plotinus. It is negatively described as a-pollon = without multiplicity. According to Gregory of Nazianzus (as quoted by Pelikan) the "only thing that could be comprehended about the incomprehensible divine nature" is its "boundlessness [apeira]"..."what it is not rather than what it is" (Pelikan 1993:41).

The epistemological issue is to acknowledge that humankind is incapable of comprehending or grasping God conceptually. Medieval reflection postulates God's aseitas, derived from the Latin expression a se esse (= to exist in and of itself). The way in which God's self-sufficiency (God's elevated aseitas) is portrayed, actually illuminates the philosophical indebtedness of theological reflection. From God's transcendent aseitas, certain attributes are deduced (such as God's eternity, omnipresence and infinity). These attributes are then designated as incommunicable and should be distinguished from the communicable attributes (love, justice, mercy, etc.).

The alternative options, emerging from the Greek-Platonic substance concept, either advocates a negative theological stance or (theo-ontologically) duplicates the creational diversity by projecting it into the "essence" of God and then once again derives creaturely properties from God. This shows that the theological tradition explored the implications of the Greek (Platonic-Aristotelian) substance concept with its mentioned distinction between being (essence) and appearance. The foundational coherence between the kinematic meaning of constancy-persistence-endurance and the physical meaning of activity-change-dynamics was distorted by the speculative split in the substance concept between an existence in itself (independent of anything beyond itself) which remains concealed behind its appearance.

\subsection{The substance concept and the distinction between theologia archetypa and theologia ectypa}

Looking back we have to notice that the initial switch to space in the metaphysics of being advocated by Parmenides and his followers caused the coherence between constancy and dynamics to acquire a spatial projection, embedded in the insideoutside opposition, elaborated by Plato (and Aristotle) into the essence-appearance distinction. This distinction between essence and appearance then informed the theological tradition and inspired it to distinguish between God's self-knowledge (theologia archetypa directed towards God as He is "in Himself") and the knowledge through which He revealed Himself to us (accommodated to creation - theologia ectypa). This distinction is also closely connected to the above-mentioned distinction between what is called communicable and incommunicable properties of God.

As an example of this legacy we look at the Dutch theologian Bavinck who explains that the theologia archetypa concerns the knowledge with which God knows himself and that the theologia ectypa is the knowledge of God as accommodated and "anthropomorphised" to be suitable for the finite human consciousness. He writes: 
"Nonetheless it contains the true conception that the theologia ectypa, which is granted to creatures through the revelation, is not the absolute self-knowledge of God, but that knowledge of God as it is accommodated to and made suitable for the finite consciousness, therefore anthropomorphized" (Bavinck, I. 1918:144 - I. 6, 4).

We briefly note that the two traditions regarding God's essence and appearance continue the essence-appearance legacy of the substance concept. The difference between the Cappadocian-Reformational (CR) legacy and the Augustine-AnselmusAquinas (AAA) tradition is a mere matter of emphasis. While the CR understanding holds on to the aseitas (causa sui or essence) of God, elevated above all appearances, the AAA understanding projects these appearances (the diversity of creational properties - or, as Aquinas calls them, perfections) into the "essence" of God - and then derive the creational diversity once again from God's essence - through the multiple ways in which the essence of God can be copied (the Platonic Urbild-Abbild schema). In his Summa contra Gentiles (I,34) and Summa Theologica (I,13,1), Thomas explains that we can know God through His creatures because, in an eminent way, God bears all the perfections of things within Himself. We know God by means of these perfections as they flow from Him into creatures (procedentibus in creaturas ab ipso - S.Th. I,13,3).

The two options are therefore: either elevate the essence of God into a realm of unknowability (which then needs the idea of accommodation of this unknowable God to creational terms in order to reveal Himself), or project the creational diversity of "perfections" into the essence of God before they are copied back into creation.

\subsection{Radical Orthodoxy - reworking Plato's view on participation}

Recenty, the movement known as Radical Orthodoxy (Milbank and others), claims that "all human knowledge is subject, under grace, to theological modification and qualification" (Milbank 2004:12). But the way in which this position is further articulated is still dependent upon the essence-appearance distinction: "Our knowledge of things of this world can always be qualified by knowledge of God as he is in himself (given by revelation)" [own italics] (Milbank 2004:13). This Platonic tradition also surfaces in a key concept of the Christology of Milbank, namely methexis (participation/sharing). It derives directly from Plato's theory of ideas where it is employed alongside the notions of parousia (presence) and koinonia

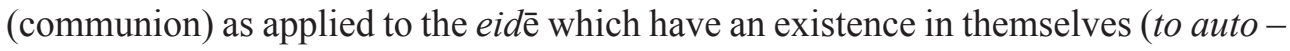
compare Pheado $100 \mathrm{D}$ where the three terms are used in connection with the eidos beauty - see Plato 1997:86). Milbank explains that the central theological framework of radical orthodoxy is found in the idea of "participation" as "developed by Plato and reworked by Christianity" (Milbank, Pickstock and Ward 2006:3). 


\section{CONCLUDING REMARKS}

In this article some of the most important elements of Greek philosophy were selected in order to illustrate the great influence of this legacy as it was mediated by Plato. Apart from the three examples discussed above (mathematics, physics and theology) the Platonic legacy is so rich that multiple volumes would be needed to trace it. For this reason we restricted our discussion to the basic exposition of Plato's views and the mediating influence they had on the mentioned academic disciplines. Plato's philosophy is simply one of the incredibly influential mile-stones on the path pursued by Western philosophy - in spite of all the criticism and further elaboration it received. Inevitable philosophical presuppositions, within diverse special sciences, underscore this fact, briefly substantiated by the examples discussed in this text (mathematics, physics and theology).

\section{REFERENCES}

Aristotle, 2001. The basic works of Aristotle. (Edited by Richard McKeon with an introduction by C.D.C. Reeve). Originally published by Random House in 1941. New York: The Modern Library.

Augustine, A. 1890. (Edited by Phili Schaff). St. Augustin's City of God and Christian doctrine. New York: The Christian Literature Publishing Co.

Bavinck, H. 1918. Gereformeerde Dogmatiek, I, Kampen: Kok.

Bernays, P. 1976. Abhandlungen zur Philosophie der Mathematik. Darmstadt: Wissenschaftliche Buchgesellschaft.

Böhme, G. 1966. Unendlichkeit und Kontinuität. In Philosophia Naturalis, Volume 2 (pp. 304$317)$.

Cantor, G. 1895. Beiträge zur Begründung der transfiniten Mengenlehre. In Mathematische Annalen, Volume 46 (pp.481-512) and Cantor 1897 Volume 49 (pp.207-246).

Cantor, G. 1962. Gesammelte Abhandlungen Mathematischen und Philosophischen Inhalts. Hildesheim: Oldenburg Verlag (1932).

Cassirer, E. 1957. Das Erkenntnisproblem in der Philosophie und Wissenschaft der neueren Zeit. Stuttgart: Kohlhammer Verlag.

Chase, M. 2014. Time and eternity from Plotinus and Boethius to Einstein. In: $\Sigma \mathrm{XO} \Lambda \mathrm{H}$ Vol. 8. 1:68-110.

Copleston, F. 1985. A history of philosophy. Volume 1, New York: Doubleday.

Cusanus, N. 1997. De Docta Ignorantia (On Learned Ignorance [1440.]). In Selected spiritual writings/Nicholas of Cusa; translated and introduced by H. Lawrence Bond; preface by Morimichi Watanabe. New York, NY: Paulist Press.

Darwin, C. 1859. On the origin of species by means of natural selection or the preservation of favoured races in the struggle for life. (Edited with an introduction by J.W. Burrow). Hardmondsworth: Penguin Books 1968. The version available on the WEB (accessed 29 
October 2005): http://www.infidels.org/library/historical/charles_darwin/origin_of_species/ Intro.html slightly differs in some respects from the Penguin edition.

Descartes, R. 1965. A discourse on method, meditations and principles. (Translated by John Veitch, introduced by A.D. Lindsay). London: Everyman's Library.

d'Espagnat, B. 2006. On physics and philosophy. Princeton: Princeton University Press.

Diels, H. and Kranz, W. 1959-60. Die Fragmente der Vorsokratiker. Vols. I-III. Berlin: Weidmannsche Verlagsbuchhandlung.

Einstein, A. 1959. Autobiographical notes. In Albert Einstein, philosopher-scientist. (Edited by P.A. Schilpp). New York: Harper Torchbooks.

Einstein, A. 1982. Grundzüge der Relativitätstheorie. Reprint of the 1969 Braunschweig edition (original edition 1922). Wiesbaden: Friedrich Fieweg \& Sohn.

Fraenkel, A., Bar-Hillel, Y., Levy, A. and Van Dalen, D. 1973. Foundations of set theory, 2nd revised edition. Amsterdam: North Holland.

Fränkel, H. 1968. Zeno von Elea im Kampf gegen die idee der Vielheit. In Gadamer, 1968:421442.

Fowler, D. 1999. The mathematics of Plato's Academy. (Second Edition). Oxford: Clarendom Press.

Gadamer, H.G. (Ed.). 1968. Um die Begriffswelt der Vorsokratiker. Wege der Forschung, Volume IX, Darmstadt: Wissenschaftliche Buchgesellschaft.

Gray, J. 2008. Plato's ghost, the modernist transformation of mathematics. Princeton: Princeton University Press.

Guthrie, W.K.C. 1980. A history of Greek philosophy. Volume II. The Presocratic tradition from Parmenides to Democritus. Cambridge: Cambridge University Press.

Happ, H. 1971. Hylē, Studien zum aristotelischen Materie-Begriff, Berlin: De Gruyter.

Heimsoeth, H. 195? (date not specified). Die sechs grossen Themen der abenländischen Metaphysik und der Ausgang des Mittelalters. Stuttgart : Kohlhammer.

Heyting, A. 1971. Intuitionism. Amsterdam: North Holland.

Hilbert, D. 1925. Über das Unendliche. In Mathematische Annalen, 1925(95):161-190.

Husserl, E. 1970. Philosophie der Arithmetik mit erganzenden Texten 1890-1901 (1891). Den Haag: Nijhoff.

Jaeger, W. 1945. Paideia: the ideals of Greek culture translated from the German by Gilbert Highet. New York: Oxford University Press.

Jäger, G. 1967. “Nus” in Platons Dialogen. Göttingen: Vandenhoeck Ruprecht.

Krämer, H.J. 1959. Arete bei Plato und Aristoteles, Zum Wesen und Geschichte der platonischen Ontologie, Heidelberg: Winter.

Krämer, H.J. 1964. Der Ursprung der Geistmetaphysik. Untersuchungen zur Geschichte des Platonismus zwischen Platon und Plotin. Amsterdam : Schippers.

Laugwitz, D. 1986. Zahlen und Kontinuum. Eine Einführung in die Infinitesimalmathematik. Darmstadt: Wissenschaftliche Buchgesellschaft. 
Leibniz, G.W. 1965. Philosophical Writings. London: Everyman's Library. (Translated by M. Morris, with an introduction by C.R. Morris). [Section: New Essays on the Human Understanding.]

Lorenzen, P. 1960. Die Enstehung der exakten Wissenschaften. Berlin: Springer.

Lorenzen, P.1972. Das Aktual-Unendliche in der Mathematik, From: Methodisches Denken, reprinted in: Meschkowski, 1972 (pp.157-165).

Maimon, S. 1790. Versuch über die Transzendentalphilosophie, mit einem Anhang uber die symbolische Erkenntnis und Anmerkungen. Berlyn (unaltered reprint by the Wissenschaftliche Buchgesellschaft, Darmstadt, 1972). An English translation appeared in 2010: Maimon, S. 2010. Essay on transcendental philosophy. (Translated by Nick Midgley, Henry SomersHall, Alistair Welchman, and Merten Reglitz). London, New York: Continuum International Publishing Group.

Meschkowski, H. 1972. Grundlagen der modernen Mathematik. Darmstadt: Wissenschaftliche Buchgesellschaft.

Milbank, J. 2004. Foreword. In Smith, 2004:11-20.

Milbank, J., Pickstock, C., and Ward, G. (Eds.). 2006. Radical Orthodoxy (first published in 1999). New York: Routledge.

Mühlenberg, E. 1966. Die Unendlichkeit Gottes bei Gregor von Nyssa. Göttingen: Vandenhoek \& Ruprecht.

Myhill, J. 1952. Some philosophical implications of mathematical logic. In The Review of Metaphysics, Vol. VI(2), December (pp.165-198).

Pelikan, J. 1993. Christian and classical culture. The metamorphosis of natural theology in the Christian encounter with Hellenism. New York: Yale University Press.

Plato, 1997. Complete works, with introduction and notes, by John M. Cooper, Associate Editor D.S. Hutchinson. Indianapolis/Cambridge: Hackett Publishing Company.

Plotinus, 1956. Enneads. (Translated by S. MacKenna). London: Faber \& Faber.

Poincaré, H. 1902. Du role de l'intuition et de la logique en mathematiques. C.R. du Iime Congress Intern. des Math., Paris, 1900:200-202.

Poincaré, H. 1910. Sechs Vorträge aus der reinen Mathematik und mathematischen Physik, Fünfter Vortrag: Über transfinite Zahlen. Leibzig und Berlin: Druck und Verlag von B. G. Teubner.

Reid, C. 1970. Hilbert, with an appreciation of Hilbert's mathematical work by Hermann Weyl. New York: George Allen \& Unwin.

Reidemeister, K. 1974. Das exakte Denken der Griechen. Beiträge zur Deutung von Euklid, Plato und Aristoteles. Darmstadt: Wissenschaftliche Buchgesellschaft (Hamburg: Reihe Libelli 1949).

Riedweg, C. 2005. Pythagoras: His life, teaching, and influence. Ithaca: Cornell University Press.

Russell, B. 1956. The principles of mathematics. London: George Allen \& Unwin. (First published in 1903, Second edition 1937, Seventh edition 1956).

Schilder, K. 1948. Christus en Cultuur. Franeker: Wever.

Simpson, G.G. 1969. Biology and man. New York: Harcourt.

Smith, J.K.A. 2004. Introducing Radical orthodoxy, Mapping a post-secular theology. (Foreword by John Milbank). Grand Rapids: Baker Academic. 
Stegmüller, W. 1987. Hauptströmungen der Gegenwartsphilosophie. Volume III, Stuttgart: Alfred Kröner Verlag.

Strauss, D.F.M. 2004. Paradigms in mathematics, physics, and biology: Their philosophical roots. (Second Edition). Bloemfontein: Tekskor BK.

Ter Horst, G. 2008. De ontbinding van de substantie. Een deconstructie van de beginselen van vorm en materie in de ontologie en de kenleer van Thomas van Aquino. Delft: Eburon.

Verdenius, W.J. and Waszink, J.H. 1968. Aristotle on coming to be and passing away. Leiden: E.J. Brill.

Von Fritz, K. 1945. The discovery of incommensurability by Hippasus of Metapontum, Annals of Mathematics, 46, 1945 (pp.242-264).

Von Weizsäcker, C.F. 2002. Große Physiker, Von Aristoteles bis Werner Heisenberg. Münhen: DTV.

Weyl, H. 1931. Die Stufen des Unendlichen. Vortrag, gehalten am 27. Oktober 1930 bei der Eröffnung der Gästetagung der methamatischen Gesellschaft an der Universität im Abbeanum. Jena.

Weyl, H. 1946. Mathematics and Logic. American Mathematical Monthly, Vol. 53:1-13.

Weyl, H. 1970. David Hilbert and his mathematical work. In: Reid, 1970.

Whitehead, A.N. 1929. Process and reality: An essay in cosmology. Cambridge: Cambridge University Press.

Wichman, O. 1966. Platon, Ideelle Gesamtdarstellung und Studienwerk. Darmstadt: Wissenschaftliche Buckgesellschaft.

Yourgrau, P. 2005. A world without time. The forgotten legacy of Gödel and Einstein. London: Penguin Books. 
